DOI: $10.20472 / E S .2019 .8 .2 .010$

\title{
FDI, GOVERNMENT BUDGET AND EFFICIENCY OF PUBLIC INFRASTRUCTURE CAPITAL
}

\author{
VIDA VARAHRAMI, ARGHAVAN NOVIN VAJARI
}

\begin{abstract}
:
This paper surveys relation between government budget, foreign direct investment (FDI) and public capital efficiency role in the infrastructure sector for attracting FDI. To achieve this goal, dynamic optimization methods are used for extracting the growth path of public consumption expenditure of government within a neoclassical growth model framework. The results suggest that FDI has a direct and positive effect on the optimal growth rate of public consumption expenditure. In fact, if the government invests more in the infrastructure sector and it is more efficient to attract FDI, the optimal growth rate of public consumption will be higher in long run respect to short run. The equation for the growth rate of public consumption is derived and estimated on the basis of data during the period 1971 - 2014 in Iran.
\end{abstract}

\section{Keywords:}

Foreign Direct Investment, Infrastructures, Public Consumption Expenditure, Long Run Growth Path, Dynamic Optimization

JEL Classification: F21, H54, O40

\section{Authors:}

VIDA VARAHRAMI, Shahid Beheshti University, Tehran, Iran, Email: vida.varahrami@gmail.com ARGHAVAN NOVIN VAJARI, Tehran University, Iran, Email: a.novin66@gmail.com

\section{Citation:}

VIDA VARAHRAMI, ARGHAVAN NOVIN VAJARI (2019). FDI, Government Budget and Efficiency of Public Infrastructure Capital . International Journal of Economic Sciences, Vol. VIII(2), pp. 148-158., 10.20472/ES.2019.8.2.010 


\section{Introduction}

In some countries, such as Iran, the government and its policy play an important role in changing and determining major macroeconomic variables. One of the important and effective government policies, especially for economic growth, is public capital policy. Therefore, determinants of public capital and their effect on other variables are of special importance that needs to be investigated.

Also, in Iran, the lifting of sanctions ${ }^{1}$ facilitates international economic transactions and provides opportunities to improve economic performance. The attraction of foreign direct investment (FDI) is one of the aforementioned opportunities. So, implementing appropriate policies to attract foreign investors and assessing the effect of FDI on the domestic economy are inevitable.

In order to attract FDI, governments should make policies and design strategies. They should allocate part of public investment to infrastructure sectors. Since poor infrastructures increase economic activity costs and reduce return on capital and consequently FDI attraction, the government needs to encourage foreign investments by providing and improving appropriate infrastructure such as roads, ports, airports, phone and internet. Of course, the effectiveness of this infrastructure for FDI attraction must not be forgotten.

On the other hand, FDI, in host countries, promotes public investment by establishing a separate sector. Moreover, it can increase government consumption expenditure because host countries become more vulnerable to international economic shocks and as a result, for protecting the domestic economy from outside economic shocks, governments should spend more funds in public consumption section.

Therefore, this interaction between government budget (and policy) and foreign FDI encouraged authors of this paper to investigate how to maximize the utility of individuals subject to these constraints.

This paper analyses the impact of public and private capital and FDI on public consumption expenditure growth rate of government by neoclassical endogenous growth model.

The rest of this paper is organized as follows: Section 1 provides a brief summary of the previous literature. Section2 extracts the dynamic model; In section3 empirical analysis and results are presented; Finally, Section 4 concludes the paper.

\footnotetext{
${ }^{1}$ In 2006, the UN Security Council passed Resolution 1696 and imposed sanctions after Iran refused to suspend its uranium enrichment program. U.S. sanctions initially targeted investments in oil, gas and petrochemicals, exports of refined petroleum products, and business dealings with the Iranian Revolutionary Guard Corps. This encompasses banking and insurance transactions (including with the Central Bank of Iran), shipping, web-hosting services for commercial endeavors, and domain name registration services. The European Union has imposed restrictions on cooperation with Iran in foreign trade, financial services, energy sectors and technologies, and banned the provision of insurance and reinsurance by insurers in member states to Iran and Iranian-owned companies. On 23 January 2012, the EU agreed to an oil embargo on Iran, effective from July, and to freeze the assets of Iran's central bank. On 17 March 2012, all Iranian banks identified as institutions in breach of EU sanctions were disconnected from the SWIFT, the world's hub of electronic financial transactions. https://en.wikipedia.org/wiki/Sanctions against Iran
} 


\section{Literature Review}

There are numerous empirical studies which have attempted to verify the policies to attract FDI. Some analysts argue FDI attraction by public investment. For instance, Lautier and Moreaub (2012) survey the impact of (private and public) domestic investment on FDI in developing countries.

Some researchers consider public infrastructure investment acts as a proxy for public investment for attracting FDI. In other words, they analyse the effect of public investment through the improvement of public infrastructure. Some of these studies indicate that infrastructure has a positive effect on FDI (Kumar, 1994; Loree \& Guisinger, 1995; Mottaleb, 2007; Demirhan \& Masca, 2008; Behname, 2012) in Iran (Shahabadi \& Mahmodi, 2006; Jafarnejad et al., 2009; Barzelaghi, 2012). Moreover there are papers which suggest that infrastructure does not have a robust effect on FDI (Blonigen \& Piger, 2014).

Asiedu (2002) analyses the determinants of foreign direct investment in 71 developing countries (32 sub-Saharan Africa (SSA) countries and 39 nonSSA). This paper considers return on investment, infrastructure development and trade openness as independent variables. Results support a positive significant impact of infrastructure on FDI in non-SSA countries. However, this is not the case for SSA countries since foreign investment to SSA is usually located in natural resource-based sector. Davoudi \& Shahmoradi (2004) reinvestigate the FDI determinants in 47 developed and developing countries (including Iran) during 1990-2002. This conclusion suggests domestic investment in infrastructure can be a complement and an attraction for FDI. Also, an enhancing infrastructure investment's efficiency is an important factor to attract FDI. Khachoo \& Imran Khan (2012) study the determinate of FDI based on a sample of 32 developing countries from 1982 to 2008. Electric power consumption has been considered as a proxy for infrastructure. The results of this paper show that since improved and efficient infrastructure facilities can increase productivity of investment (which stimulates FDI inflow), infrastructure has a positive significant effect on FDI. Alavinasab (2013) studies determinants of FDI in Iran for the period of 1991-2009. This paper uses infrastructure (by paved road), government consumption and some other variables in its model. The results indicate the positive significant effect of infrastructure and positive insignificant effect of government consumption on FDI. In this paper, we indicate that FDI has a direct and positive effect on the growth rate of public consumption expenditure which differs from Alavinasab (2013). Also, it implies that the effectiveness of FDI on the long-run growth rate of public consumption greatly depended on the efficiency of public capital to attract FDI.

Morita and Sugawara (2015) construct an overlapping generation's model with human capital accumulation to analyze the effect of human capital level on FDI in a small open developing country. When the level of human capital is sufficiently large, manufacturers conduct FDI in equilibrium and the income of the developing country increases. They show that if the government of the developing country levies a tariff on the imports of 
manufactured goods, manufacturers conduct FDI and the economy in the developing country can escape from poverty trap.

Also, there are numerous articles that survey interaction between FDI and investment or infrastructure (Ndikumana \& Veric, 2008; Nourzad et al., 2014). Pradhan et al. (2013) investigate the long-run interaction between FDI, transport infrastructure and economic growth in India during 19702012. The results show all main variables have a positive effect on others. Ditimi and Matthew (2014) investigate the interactions between FDI, private direct investment and public direct investment in Nigeria by using a multivariate VAR model. The results show, in the long run, there is no interaction among private, public investment and FDI. This paper suggests that promotion of public infrastructure and economic condition could increase the poor interaction between these three types of investments.

Furthermore, the empirical studies which examined relationship between FDI and government consumption expenditure are rare. Therefore, we survey some papers about FDI and government size that implicitly indicate the relationship between FDI and government expenditure. Some papers indicate that FDI has positive significant impact on government size or expenditure (Sanz \& Velazquez, 2003) and others have opposite view (Liberati, 2007; Wu \& Lin, 2012).

Gemmell et al. (2008) examine a dynamic model of 25 OECD countries during 1980-1997. Results show that an increase in foreign direct investment shifts government expenditure towards social spending.

\section{Model}

In this section, we consider a model for Iranian economy according to the neoclassical model we assume the production function as follows:

$$
\mathrm{Y}_{\mathrm{t}}=\mathrm{A}\left(\mathrm{K}_{\mathrm{gt}}\right)^{\alpha} \mathrm{K}_{\mathrm{t}}^{1-\alpha}=\mathrm{A}\left(\frac{\mathrm{K}_{\mathrm{gt}}}{\mathrm{K}_{\mathrm{t}}}\right)^{\alpha} \mathrm{K}_{\mathrm{t}} \quad 0<\alpha<1
$$

This model is an extended model of $\mathrm{AK}$ in which $\mathrm{K}$ depends on the ratio of public capital $\left(\mathrm{K}_{\mathrm{gt}}\right)$ to private capital $\left(\mathrm{K}_{\mathrm{t}}\right)$. According to Rebelo (1991), in order to have a feasible endogenous steady state growth (in AK form), this function requires constant returns to scale in the accumulated factors (i.e., state variables: public capital stock and private capital stock). This model has long run steady state growth rate and also deep parameters and different policy can affect the long run growth rate ${ }^{1}$. It also embodies the assumption that public capital enhances the productivity of private capital, though at a diminishing rate $^{2}$ because of $(\alpha)$.

For simplicity and following the endogenous growth theory literature, population growth rate is assumed zero and thus, aggregate quantities of variables equal their per capita. Also, we assume that the government is in charge of FDI attraction policies and it can improve FDI attraction by investing in infrastructure projects. For this reason, FDI can be a function of

1 - Kavand \& Novin (2013)

2 - Turnovsky (1997) 
public investment which spends on improving conditions to attract FDI. So, FDI can be written as:

$$
\mathrm{FDI}_{\mathrm{t}}=\chi(1-\epsilon)^{(1-\beta)} \mathrm{K}_{\mathrm{gt}} ; 0<\beta<1,
$$

Where $\mathrm{FDI}_{\mathrm{t}}$ foreign direct investment is increased by enhancing public infrastructure capital at diminishing returns, $(\varepsilon)$ represents the share of public investment used in non-infrastructure and $\beta$ indicates public investment efficiency to FDI attraction. When $\beta \rightarrow 0$ and $\beta \rightarrow 1$, public investment in infrastructure has respectively less and more effect on FDI attraction. The $(\chi)$ represents other variables such as changes in the exchange rate, sanctions, human capital, etc. which affect FDI promotion.

Since government consumption expenditure is funded by tax and oil revenue and government capital expenditure is funded by tax, oil revenue and foreign direct investment, thus:

$$
\begin{gathered}
G_{\mathrm{t}}^{\mathrm{c}}=\vartheta\left(\tau_{\mathrm{t}} \mathrm{Y}_{\mathrm{t}}+\theta \mathrm{or}_{\mathrm{t}}\right) \\
G_{\mathrm{t}}^{\mathrm{i}}=(1-\vartheta)\left(\tau_{\mathrm{t}} \mathrm{Y}_{\mathrm{t}}+\theta 0 \mathrm{or}_{\mathrm{t}}\right)+F D I_{t},
\end{gathered}
$$

Therefore, the government budget balance is:

$$
G_{\mathrm{t}}^{\mathrm{c}}+G_{\mathrm{t}}^{\mathrm{i}}=\tau_{\mathrm{t}} \mathrm{Y}_{\mathrm{t}}+\theta \text { or }_{\mathrm{t}}+F D I_{t}
$$

Where $\tau_{t}$ is the tax rate, $\theta$ is the percentage of oil revenue spent on the government budget. $G_{t}^{i}$ is government capital expenditure and $G_{t}^{c}$ is government consumption expenditure at time t. Also, according to Turnovsky(1997) the capital depreciation rate is assumed zero( $\dot{K}_{\mathrm{gt}}=$ Gti.The variable $\vartheta$ is the percentage of oil and tax revenue spent on government consumption expenditure.

Resource constraints for households in total economy can be defined:

$$
\dot{\mathrm{K}}_{\mathrm{t}}=\left(1-\tau_{\mathrm{t}}\right) \mathrm{Y}_{\mathrm{t}}-\mathrm{C}_{\mathrm{t}}
$$

Where $\mathrm{C}_{\mathrm{t}}$ is the consumption goods. We assume $\dot{\mathrm{K}}_{\mathrm{t}}=0$ (according to Kavand \& Novin (2013)), supply and demand are in balance.

Also, we use a utility function that is quasi-concave and Constant Intertemporal Elasticity Substitution (CIES) and it satisfies the Inada conditions. This is because a constant coefficient of relative risk aversion (or the reciprocal of the Inter-temporal Elasticity Substitution) is required to have coefficients with a constant growth rate in the steady state. According to Ghosh and Mourmouras (2002), Kavand and Novin (2013) and the growth theories literature, we define the utility function as follow:

$$
\mathrm{u}\left(\mathrm{C}, \mathrm{C}^{*}, \mathrm{G}_{\mathrm{t}}^{\mathrm{c}}\right)=\alpha \frac{\mathrm{C}_{\mathrm{t}}^{1-\psi}}{1-\psi}+\beta \frac{\left(\mathrm{G}_{\mathrm{t}}^{\mathrm{c}}\right)^{1-\eta}}{1-\eta},
$$

Where, $\frac{1}{\psi}$ and $\frac{1}{\eta}$ are respectively CIES of $C_{t}$ and $G_{t}^{c}$. Also, $\alpha$ and $\beta$ indicate the importance of private and public consumption in this utility function.

This problem is solved by using the current value Hamiltonian function and the derivation of the first order condition.

From the first order condition, we have $\mathrm{u}_{\mathrm{G}_{\mathrm{t}}^{\mathrm{c}}}=\mathrm{u}_{\mathrm{C}_{\mathrm{t}}}$. In other words, under the optimal condition, when transferring a unit of income tax revenue to the government will be justified, the marginal utility from increasing government expenditure is greater than the marginal utility of consumer expenditure . Thus, tax rate should be determined based on $\mathrm{u}_{\mathrm{G}_{\mathrm{t}}^{\mathrm{c}}}=\mathrm{u}_{\mathrm{C}_{\mathrm{t}}}$. 
With the first order condition, Hamiltonian maximization and proper substitutions, it can be written as:

$$
\frac{\dot{C_{\mathrm{t}}}}{\mathrm{C}_{\mathrm{t}}}=\frac{1}{\psi}\left((1-\alpha) \mathrm{A} \frac{\left(\mathrm{K}_{g \mathrm{t}}\right)^{\alpha}}{\mathrm{K}_{\mathrm{t}}^{\alpha}}-\rho\right),
$$

It describes that the growth rate of private consumption function depends on the difference between marginal production of private capital and its opportunity cost (because $\rho$ is the rate of time preference). It implies the direct relation between public capital and private consumption growth rate. It means greater public, capital results in the greater private consumption growth rate. Likewise, FDI is not shown explicitly in the above equation but it could have indirectly positive effect on private consumption growth rate, because it can increase the public capital by providing part of it. Also, higher $\frac{1}{\psi}$ or the easier households change their consumption yields, the higher private consumption growth rate. This is because households are more willing to postpone consumption in response to high saving and invest it in future that leads to greater production and consequently the higher consumption growth rate.

Also, with the first order condition, Hamiltonian maximization and some substituting, it can be written as:

$$
\frac{\dot{\mathrm{G}_{\mathrm{t}}^{\mathrm{c}}}}{\mathrm{G}_{\mathrm{t}}^{\mathrm{c}}}=\frac{1}{\eta}\left\{\alpha \mathrm{A} \frac{\mathrm{K}_{\mathrm{t}}^{1-\alpha}}{\left(\varepsilon \mathrm{K}_{g \mathrm{t}}\right)^{1-\alpha}}+\left(\chi(1-\epsilon)^{(1-\beta)}\right)-\rho\right\},
$$

It indicates the growth rate of public consumption function. It suggests this growth rate depends on public and private capital, the ratio of FDI to the public capital and $\rho$. The more efficient is the public capital in FDI attraction $(\beta \rightarrow 1)$, the greater is the public consumption growth rate. FDI in (9), unlike in (8), is observed directly. In other words, a government can improve its public consumption growth rate by attracting more FDI.

$(\chi)$ in (9) shows any exogenous factors such as changes in exchange rate and international financial sanction can directly affect on the growth rate of public consumption. In other words, if a long run international sanctions imposed against a country's government interaction that depend on foreign direct investment and if these sanctions are not compatible with the efficiency of public infrastructure capital(with the assumption that private section has not any role), the consumption expenditure growth rate of this government will be affected.

Now, for examining this achieved equation we estimate it based on data for Iran over the period 1971-2014.

\section{Empirical Results}

We should estimate (8) and (9). But (8) is examined in many articles discussing the growth model' Therefore, we will only estimate (9). To investigate the equation for the growth rate of public consumption, we should proceed with the log linearization strategy. Therefore, we have the following log-linearized equation:

$$
\begin{gathered}
\frac{\dot{\mathrm{G}_{\mathrm{t}}^{c}}}{\mathrm{G}_{\mathrm{t}}^{\mathrm{c}}}=\beta_{0}+\beta_{1} \ln \left(K_{t}\right)+\beta_{2} \ln \left(\mathrm{K}_{g \mathrm{t}}\right)+\beta_{3} \ln \left(\frac{\mathrm{FDI}}{\mathrm{K}_{g \mathrm{t}}}\right)+\varepsilon_{\mathrm{t}}, \\
\beta_{1}>0, \beta_{2}<0, \beta_{3}>0,
\end{gathered}
$$


Variables are per capita. The final data used for the growth rate of public consumption expenditure $\left(\frac{G_{t}^{c}}{G_{t}^{c}}\right)$ are provide by the government, gross fixed capital formation by private sector data for private capital $\left(K_{t}\right)$, gross fixed capital formation by public sector data for public capital $\left(\mathrm{K}_{g \mathrm{t}}\right)$ and ratio of Foreign direct investment, net inflows (current US\$) divided by implicit price deflator to gross fixed capital formation by public sector data for ratio of FDI to public capital $\left(\frac{\mathrm{FDI}}{\mathrm{K}_{g \mathrm{t}}}\right)$. These data exception FDI come from Central Bank of Iran and FDI data is obtained from the World Bank's online database for Iran during 1971-2012. Now, we use ADF test to find whether the variables are stationary.

Table 1: Results of Unit Root Test

\begin{tabular}{|c|c|c|c|c|}
\hline Variable & $\begin{array}{c}\text { ADF Test } \\
\text { Static }\end{array}$ & $\begin{array}{c}\text { ADF Critical } \\
\text { Value }\end{array}$ & P-Value & $\begin{array}{c}\text { Order of } \\
\text { Integration }\end{array}$ \\
\hline & -68.4 & -32.4 & 0.95 & Stationary \\
\hline & -66.3 & -28.5 & 0.95 & Stationary \\
\hline & -71.3 & -62.3 & 0.95 & Stationary \\
\hline & -3.75 & 3.66 & 0.95 & Stationary \\
\hline
\end{tabular}

Source: Authors' own calculation

As the above table shows, log of public capital, private capital, ratio of FDI to public capital and the growth rate of public consumption expenditure are stationary.

The result of the long-run relationship between variables in (10) is:

Table 2: Estimated Regression (Long-Run Coefficients)

\begin{tabular}{|c|c|c|}
\hline Variable & Coefficient & t-statistic \\
\hline C(Intercept) & 13.07 & $\mathbf{6 . 7 6}$ \\
\hline & 1.37 & $\mathbf{9 . 3 9}$ \\
\hline & -0.7 & $\mathbf{1 0 . 0 1}$ \\
\hline Regression statistics & 0.53 & 6.76 \\
\cline { 2 - 3 } & & D.W=2.03 \\
\cline { 2 - 3 } & $\mathrm{R}^{2}=0.95$ & Prob(F-Stat $)=0.0$ \\
\hline
\end{tabular}

Source: Authors' own calculation

According to the above table containing the long run estimated coefficient, private capital and the ratio of FDI to public capital have a positive significant impact on the growth rate of public consumption expenditure while the effect of public capital is negative significant. Therefore, the results for long run support our model.

Furthermore, the short run relationship between variables in (10) yields the following result: 
Table 3: Estimated Regression (Short-Run Coefficients)

\begin{tabular}{|c|c|c|}
\hline Variable & Coefficient & t-statistic \\
\hline C (Intercept) & 12.08 & 6.62 \\
\hline & 1.21 & 9.81 \\
\hline & -0.63 & 10.26 \\
\hline & 0.49 & 5.32 \\
\hline ECM(-1) & -0.38 & 4.66 \\
\hline Regression statistics & $R^{2}=0.94$ & D.W=2.01 \\
\cline { 2 - 3 } & $\mathrm{F}=438.5$ & Prob(F-Stat) $=0.0$ \\
\hline
\end{tabular}

Source: Authors' own calculation

The above table shows, as in the long run model, the ratio of FDI to public capital and private capital have a positive significant effect on public consumption expenditure growth rate, and the impact of public capital on it is negative and significant. Long run coefficients of public and private capital and FDI to public capital are more than short run coefficients.

Also, the ECM (-1), given in the recent table, indicates the speed of adjustment with which variables return to equilibrium. The coefficient of 0.38 for ECM (-1) implies the deviation from the long run inequality is corrected by 38 percent over each year. Since the coefficient lies between 0 and 1 and it is significant from static view. Then the existence of a stable long run relationship between these variables is acceptable.

Thus, the above two estimation results support our model.

\section{Conclusion}

We investigated the effect of FDI on the government budget. In fact, we have analysed the role of public capital efficiency in the infrastructure sector to attract FDI. Furthermore the long run and short run effects of FDI on growth rate of public consumption expenditure of government was studied within a neoclassical growth model framework.

The derived relations indicated that the optimal growth rate of public consumption expenditure depends on the private and public capital and FDI. Furthermore, this paper extracted the equation for the growth rate of public consumption expenditure. The equation of the growth rate of public consumption is estimated on the basis of data from 1971 to 2014 in Iran. It indicated that FDI has a direct and positive effect on the grow rate of public consumption expenditure (in long run and short run). Also, it implies that the effectiveness of FDI on growth rate of public consumption greatly depended on public capital efficiency to attract FDI. It means that public consumption cannot have a high growth rate if investment in the infrastructure sector is not sufficient and the rate of return on its public capital to FDI attraction is not high.

The outcome of estimation supports, government can improve its public consumption growth rate by attracting more FDI. Three reasons are discussed here: first, governments can provide a part of public capital by 
foreign investment and in result it can allocate a large share of public funds to public consumptions. Second, a country that attracts and has more foreign investments is more vulnerable to international shocks. For this reason, the government should allocate more funds to public consumption in order to be stabilized. Third, host governments should provide goods and require conditions for holding foreign investors. Therefore, they should spend more funds on consumption expenditure. Also, the effectiveness of FDI on growth rate of public consumption is greatly relied on public capital efficiency to attract FDI. It means that if the investment in infrastructure sector is not sufficient and the marginal rate of return on its public capital to FDI attraction is low, the public consumption cannot have high growth rate in long-run.

\section{References}

Alavinasab, S.M., (2013), Determinants of Foreign Direct Investment in Iran, International Journal of Academic Research in Business and Social Sciences, 3, .258-269

Asiedu, E., (2002). On the determinants of foreign direct investment to developing countries: is Africa different?, World Development, 301, 107119.

Barro, R.J. 1990, Government spending in a simple model of endogenous growth, Journal of Political Economy, 98, 103-124.

Behname, M., (2012), Foreign Direct Investment and Urban Infrastructure an Evidence from Southern Asia, Advances in Management \& Applied Economics, 2, 253-259

Blonigen, B.A. and Piger P., (2014), Determinants of Foreign Direct Investment, Canadian Journal of Economics, 47, 775-812.

Davoodi, P. and Shahmoradi, A., (2004), Recognition of factors affecting the economy and attract foreign direct investment in Iran and 46 countries in the framework of an integrated model, Iranian Economic Research, 6, 81113

Demirhan, E. and Masca, M., (2008), Determinants of Foreign Direct Investment Flows to Developing Countries: A Cross- Sectional Analysis, Prague Economic Paper, 17, 356-369

Ditimi, A. and Matthew, O., (2014), FDI, Private Investment and Public Investment in Nigeria: An Unravelled Dynamic Relation, Journal of Business \&Economic Policy, 1, 29-38.

Futagami, K., Y. Morita, A. Shibata, 1993, Dynamic analysis of an endogenous growth model with public capital, Scandinavian Journal of Economics, 95, No. 4, 607-625.

Gemmell, N., Kneller, R., Sanz, I., (2008), foreign investment, international trade, and the size and structure of public expenditures, European Journal of Political Economy, 24, 151-171.

Ghosh, S. and Mourmouras A., (2002), On public investment, long-run growth, and the real exchange rate, Journal of Oxford Economic, 54, 72-90 
Jafarnejad, A., Golnam, A. and Ale Ebrahim N., (2009), Determinants of foreign direct Investment in IRAN: An Empirical Study Using Structural Equation Modelling, Middle East FORUM, 9, 71-83.

Khachoo, A.Q. and Khan, M.I., (2012), Determinants of FDI Inflows to Developing Countries: A Panel Data Analysis, MPRA Paper, No. 37278.

Kumar, N., (1994), Determinants of Export Orientation of Foreign Production by US Multinationals: An Inter-Country Analysis, Journal of International Business Studies, 25, 141-156.

Kavand, H. and Novin Vajari, A., (2013), The Role of Public Investment on Long Run Economic Growth: A Neoclassical Endogenous Growth Model, Journal of Economic Research (Tahghighat-e-eghtesadi), 48, 87-106

Lautier, M. and Moreaub, F., (2012), Domestic Investment and FDI in Developing Countries: The Missing Link, Journal of Economic Development, 37

Liberati, P., (2007), Trade Openness, Financial Openness and Government Size, Journal of Public Policy, 27, 215-247

Loree, D.W. and Guisinger, S.E., (1995), Policy and Non-Policy Determinants of U.S. Equity Foreign Direct Investment, Journal of International Business Studies, 26, 281-299.

Morita T, K. Sugawara (2015) Human Capital and FDI: Development process of the developing country in an overlapping generation model, Journal of International Trade and Economic Development, 24, 922-946.

Mottaleb, K.A., (2007), Determinants of Foreign Direct Investment and Its Impact on Economic Growth in Developing Countries, Munich Personal Re PEc Archive, MPRA Paper No.9457

Ndikumana, L. and Veric, Sh., (2008), The Linkages between FDI and Domestic Investment: Unravelling the Developmental Impact of Foreign Investment in Sub-Saharan Africa, Development Policy Review, 26, 713-726 Nourzad, F.,Greenwood , D. N. and Yang, R., (2014), The Interaction Between FDI and Infrastructure Capital in The Development Process, International Advances in Economic Research, 20, 203-212

Pradhan, R., Neville, N. and Badir, Y., (2013), Transport Infrastructure, Foreign Direct Investment and Economic Growth Interactions in India: The ARDL Bounds Testing Approach, Procedia - Social and Behavioral Sciences, 104. $914-921$

Rebelo, S. T., (1991): Long-Run Policy Analysis and Long-Run Growth, Journal of Political Economy, 99, 500-521

Rodrik, D., (1998). Why do more open economies have bigger governments Journal of Political Economy, 106, 997-1032.

Sanz, L. and Velazquez, F. J., (2003), Does Globalization Increase Government Size?An analysis of the Effects of Foreign Direct Investment on Total Government Expenditures and its Components and its Components. Mimeo

Shahabadi, A, Mahmoodi, A., (2006), Determinants of foreign direct investment in Iran. BI - Quarterly Journal of Iran's Economic Essays, 5, 89123. 
Taghilou Barzelaghi, M. and Dizaji, M., (2012) The Effect of Transportation Infrastructure on Foreign Direct Investment Attraction in Iran, International Journal of Economics and Finance Studies, 4, 153-161 Turnovsky, S.J., (1997), Fiscal policy in a growing economy with public capital, Macroeconomic Dynamics, 1, 615-639.

$\mathrm{Wu}$, Alfred M. and Mi Lin. (2012); Determinants of government size: evidence from China, Public Choice. 151, 255-270 